\title{
PENGEMBANGAN MEDIA PEMBELAJARAN KEARSIPAN DIGITAL UNTUK MENINGKATKAN HASIL BELAJAR SISWA SMK NEGERI 3 SURAKARTA
}

\author{
Arif Wahyu Wirawan \\ Magister Pendidikan Ekonomi, Universitas Sebelas Maret Surakarta \\ id.arifwahyu@gmail.com \\ Cicilia Dyah Sulistyaningrum Indrawati \\ Pendidikan Administrasi Perkantoran, Universitas Sebelas Maret Surakarta \\ ciciliadyahsulistyaningrum@yahoo.com \\ Andre N. Rahmanto \\ Pendidikan Administrasi Perkantoran, Universitas Sebelas Maret Surakarta \\ andreyuda@yahoo.com
}

\begin{abstract}
Abstrak
Penelitian ini bertujuan untuk mengetahui kefektifan media pembelajaran kearsipan digital dalam meningkatkan hasil belajar siswa SMK Negeri 3 Surakarta. Penelitian ini merupakan penelitian dan pengembangan $(R \& D)$. Model pengembangan media ini menggunakan model Hannafin dan Peck. Subyek pengujian dilakukan di dua kelas, yaitu kelas X AP 1 (kelas eksperimen) dan X AP 2 (kelas kontrol) di SMK Negeri 3 Surakarta. Uji prasyarat analisis meliputi uji normalitas, uji homogenitas dan menggunakan uji-t. Teknik analisis yang digunakan deskriptif kualitatif dan kuantitatif. Hasil penelitian menunjukkan bahwa keefektifan dari media pembelajaran kearsipan digital bahwa $t_{\text {hitung }}>t_{\text {tabel }}=(3,26>2,00)$, maka $H_{0}$ ditolak, itu berarti bahwa kedua kelompok memiliki skor prestasi belajar yang berbeda. Hasil posttest antara kelas eksperimen (menggunakan media yang dikembangkan) dengan kelas kontrol (tidak menggunakan media yang dikembangkan) menunjukkan bahwa nilai rata-rata yang diperoleh kelas eksperimen adalah 80,59, nilai rata-rata lebih tinggi dari kelas kontrol 77, 97. Kesimpulan dari penelitian ini adalah pengembangan media pembelajaran kearsipan digital dianggap efektif dalam meningkatkan hasil belajar siswa SMK Negeri 3 Surakarta.
\end{abstract}

Kata kunci: kearsipan, media pembelajaran, microsoft access

\section{THE DEVELOPMENT OF LEARNING MEDIA ARCHIVES TO IMPROVE STUDENT LEARNING OUTCOMES SMK NEGERI 3 SURAKARTA}

Abstract

\begin{abstract}
This study aims to determine the effectiveness of instructional media digital archives in improving student learning outcomes SMK Negeri 3 Surakarta. This study is a research and development $(R$ $\& D)$. Models using the model of media development Hannafin and Peck. Subjects testing was conducted in two classes, X AP 1 (experimental class) and X AP 2 (control group) at SMK Negeri 3 Surakarta. Prerequisite test analysis covering the normality test, homogeneity and using $t$-test. The analysis technique used descriptive qualitative and quantitative. The results showed that the effectiveness of digital archival media learning that $t_{\text {count }}>t_{\text {table }}=(3.26>2.00)$, then $H_{0}$ is rejected, it means that the two groups had different learning achievement scores. Results posttest between the experimental class (using the media developed) with a control class (do not use the media developed) shows that the average value obtained experimental class is 80.59, the average value is higher than the control class 77, 97. Conclusion this research is the development of instructional media digital archives are considered effective in improving student learning outcomes SMK Negeri 3 Surakarta.
\end{abstract}

Keywords: archives, learning media, microsoft access 


\section{PENDAHULUAN}

Pendidikan merupakan salah satu sarana untuk menciptakan sumber daya manusia yang berkualitas. Sumber daya manusia yang berkualitas itulah yang akan membangun suatu negara sehingga dapat meningkatkan kualitas suatu bangsa. Perkembangan Ilmu Pengetahuan dan Teknologi (IPTEK) selain berpengaruh dalam dunia industri berpengaruh juga terhadap dunia pendidikan di Indonesia. Teknologi membuat efek positif tidak hanya pada sosial hidup tetapi juga pada pendidikan. Karena teknologi menjadi semakin lazim dalam pengaturan pendidikan, ada muncul harapan bagi pendidik untuk memanfaatkan alat digital untuk mendukung belajar mengajar di kelas (Akyuz \& Yavuz, 2015; Gan, Menkhoff, \& Smith, 2015; All, Nuñez Castellar, \& Van Looy, 2016).

Hal ini dilihat dari sarana prasarana dan media pembelajaran yang digunakan seorang guru dalam menyampaikan materi pada siswa. Dengan adanya kemajuan teknologi menuntut seorang guru sebagai pendidik untuk selalu berinovasi dalam menciptakan media pembelajaran yang mampu menunjang pemahaman siswa dalam mempelajari materi pelajaran baik teori maupun praktik (Lock \& Kingsley, 2007; Norman \& Furnes, 2016). Penggunaan media pembelajaran selain bertujuan untuk mempermudah dalam penyampaian materi dari guru ke siswa juga dapat meningkatkan minat serta kemauan siswa dalam suatu mata pelajaran.

Belajar bukan suatu tujuan, tetapi merupakan suatu proses untuk mencapai tujuan (Hamalik, 2011, p. 29). Keterlibatan media pembelajaran dalam proses pembelajaran diharapkan dapat berpengaruh terhadap pembelajaran yang dialami siswa serta tujuan yang hendak dicapai dalam pembelajaran itu sendiri. Penggunaan media pembelajaran dalam proses pembelajaran juga akan memberi kontribusi terhadap pengoptimalan pencapaian tujuan pembelajaran.

Pembelajaran kearsipan yang selama ini masih menekankan pada praktik penataan arsip secara konvensional dengan menggunakan filling cabinet beralih media digital/arsip virtual. Perkembangan dunia kearsipan pada era komputerisasi berkembang dengan sistem penyimpanan komputerisasi atau sering disebut Electronic Arsip (E-Arsip). Arsip meru- pakan bagian yang sangat berharga dari warisan budaya kita karena mereka mewakili jejak aktivitas seseorang fisik atau yuridis dalam perjalanan bisnis mereka (Ferro \& Silvello, 2013; Cincinelli et al., 2016; Tang, Misztal, Nazaroff, \& Goldstein, 2015; Smith, 2016).

Sekolah Menengah Kejuruan (SMK) yang disiapkan sebagai tenaga kerja yang siap kerja diharapkan dalam proses pembelajaran mampu membekali siswa dalam kompetensi keahlian yang dipelajari dan disesuaikan pada masalah dunia kerja. Kompetensi keahlian Administrasi Perkantoran memiliki mata pelajaran kearsipan pada kurikulum 2013, yang di dalamnya terdapat materi dalam penyimpanan arsip secara digital. Hasil belajar mata belajar mata pelajaran kearsipan masih belum optimal.

Salah satu solusi dalam meningkatkan daya serap siswa dalam pembelajaran kearsipan yang menonjolkan pada kemampuan mengaplikasikan konsep dasar kearsipan untuk menciptakan proses pembukuan yang baik adalah dengan mendesain pengembangan media pembelajaran. Meningkatkan daya pikir dalam proses pendidikan merupakan seperangkat keterampilan yang dapat dikembangkan melalui proses belajar (Rosalin, 2008). Guru dalam proses belajar harus mengkaitkan dan menyatukan latihan berpikir dengan penguasaan pengetahuan (substansi), sebab pengetahuan dan berpikir dapat saling melengkapi dalam perkembangan berpikir selanjutnya.

Penggunaan Microsoft Acces yaitu untuk memudahkan arsip yang tidak tersusun agar dapat tersistematis menurut Yuliana, (2007, p. 5) menyatakan Microsoft Access adalah salah satu Microsoft Office Suite yang diciptakan dan dibuat dan menangani suatu database. Menurut Westriningsih (2010, p. 234) Microsoft Access merupakan salah satu aplikasi Microsoft Office yang secara khusus dikembangkan untuk kebutuhan pemograman database. Microsoft Access merupakan program database digunakan untuk pengolahan berbagai jenis data. Microsoft Acces memiliki beberapa komponen yang mendukung akan pembuatan database atau pangkalan data diantaranya table, field, query, form, dan data yang dibutuhkan. Berdasarkan Westriningsih (2010, p. 234) Microsoft Access memiliki komponen sebagai berikut: (1) table berfungsi sebagai tempat penyimpanan kumpulan data 
yang sejenis; (2) query berfungsi sebagai bahasa untuk memanipulasi terhadap database; (3) form berfungsi memasukkan dan mengubah data atau informasi yang ada dalam suatu database dengan menggunakan tampilan formulir; (4) report berfungsi untuk menampilkan, mencetak data atau informasi.

Sekolah Menengah Kejuruan yang notabenenya menyiapkan tenaga kerja yang siap kerja diharapkan dalam proses pembelajaran mampu membekali siswanya dalam kompetensi keahlian yang dipelajari dan disesuaikan pada masalah dunia kerja. Kompetensi keahlian administrasi perkantoran memiliki mata pelajaran kearsipan pada Kurikulum 2013, yang dalamnya terdapat materi dalam penyimpanan arsip secara digital. Akan tetapi masih minimnya aplikasi penyimpanan arsip sehingga perlu adanya pengembangan inovasi media pembelajaran sangat dibutuhkan terutama dalam hal otomatisasi kearsipan. Berdasarkan permasalahan tersebut, untuk itu penulis menawarkan sebuah inovasi media pembelajaran kearsipan digital.

Berdasarkan latar belakang tertib tujuan yang akan dicapai dalam penelitian ini adalah mengembangkan media pembelajaran kearsipan digital dalam meningkatkan hasil belajar siswa SMK Negeri 3 Surakarta.

\section{METODE PENELITIAN}

Metode yang digunakan dalam penelitian ini adalah metode Research and Development, menurut Borg \& Gall (2007, p. 589) mengatakan bahwa Research and Development is an industry based development, which the findings of research are used to design new product and procedures, which then are systematically field tested, evaluated and refined until they meet specified creteria of effectiveness, quality, or similar standards. United Nation conference On Trade and Development (UNCTAD) (UNCTAD, 2005, p. 1) menjelaskan penelitian dan pengembangan (Research and Development) terdiri dari empat jenis kegiatan, yaitu: penelitian dasar, penelitian terapan, pengembangan produk, dan proses pengembangan.

Model pengembangan yang menjadi acuan dalam penelitian ini adalah desain pengembangan Hannafin \& Peck (1988). Model Hanafin dan Peck merupakan salah satu dari banyak model desain pembelajaran yang berorietasi produk. Model berorientasi produk adalah model desain pembelajaran untuk menghasilkan suatu produk, biasanya media pembelajaran (Afandi \& Badarudin, 2011, p. 22). Menurut Hanafin dan Peck (Tegeh, Jampel, \& Pudjawan, 2014, p. 1) model desain pembelajaran terdiri dari tiga fase yaitu Need Assesment, Design and Development and Implementation.

Fase pertama dari model Hannafin dan Peck adalah analisis kebutuhan. Fase ini diperlukan untuk mengidentifikasi kebutuhankebutuhan dalam mengembangkan suatu media pembelajaran termasuklah di dalamnya tujuan dan objektif media pembelajaran yang dibuat, pengetahuan dan kemahiran yang diperlukan oleh kelompok sasaran, peralatan dan keperluan media pembelajaran.

Fase yang kedua dari model Hannafin dan Peck adalah fase desain. Di dalam fase ini informasi dari fase analisis dipindahkan ke dalam bentuk dokumen yang akan menjadi tujuan pembuatan media pembelajaran.

Fase ketiga dari model Hannafin dan Peck adalah fase pengembangan dan implementasi. Hannafin dan Peck, mengatakan aktivitas yang dilakukan pada fase ini ialah penghasilan diagram alur, serta penilaian formatif dan penilaian sumatif.

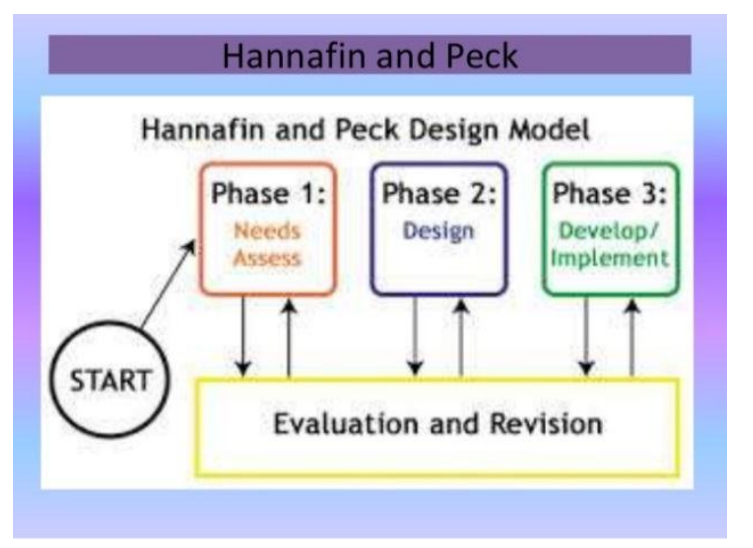

Gambar 1. Model Pengembangan Hannafin \& Peck (1988)

Teknik pengumpulan data menggunakan hasil wawancara, observasi lapangan, angket, dan tes hasil belajar.

\section{HASIL DAN PEMBAHASAN}

Pengembangan media pembelajaran kearsipan digital yang telah dilaksanakan olehe peneliti menggunakan acuan model pengembangan produk Hannafin and Peck. Langkahlangkah pengembangan media pembelajaran 
kearsipan digital ini terdiri dari tiga fase yaitu fase analisis kebutuhan, fase desain, fase pengembangan dan implementasi.

\section{Fase Analisis Kebutuhan}

Pengembangan media pembelajaran kearsipan digital diawali dengan analisis kebutuhan yang merupakan langkah pertama dalam melakukan pengembangan terhadap suatu media atau produk. Tahap analisis kebutuhan juga merupakan dasar dalam membuat suatu media. Tujuan dari dilakukannya analisis kebutuhan adalah untuk mendapatkan data pendukung pengembangan media yang dihasilkan sesuai dengan kebutuhan pengguna media. Uji coba penelitian dan pengembangan dilaksanakan di SMK Negeri 3 Surakarta. Dengan menggunakan kelas X AP 1 dan X AP 2. Pada fase analisis kebutuhan berdasarkan hasil observasi yang dilakukan dapat disimpulkan bahwa guru mengalami kesulitan dalam menyampaikan materi pelajaran. Mata pelajaran tersebut adalah mengidentifikasikan organisasi dan masalah pokok kearsipan serta kedudukan kearsipan dalam organisasi. Guru juga mengalami kesulitan dalam membuat media pembelajaran sehingga dalam memberikan contoh visual kepada siswa masih kurang maksimal. Oleh karena itu perlu adanya pengembangan media pembelajaran yang disesuaikan dengan materi pembelajaran di SMK Negeri 3 Surakarta Bidang Keahlian Administrasi Perkantoran. Hal ini didukung dengan sarana dan prasarana yang memadai seperti LCD Proyektor, laptop atau komputer yang dapat digunakan dengan mudah oleh siswa. Media ini bisa digunakan untuk media pembelajaran secara mandiri oleh siswa, diharapkan dengan pengembangan media pembel- ajaran digital siswa dapat menguasai materi dengan baik dan dapat memiliki motivasi lebih dalam belajar sehingga hasil belajar dapat meningkat.

\section{Fase Desain}

Pada tahap fase desain didasarkan pada hasil observasi dalam kegiatan analisis kebutuhan yang merupakan langkah awal persiapan memproduksi sebuah media pembelajaran. Peneliti membuat storyboard yang merupakan rancangan secara umum. Desain dan storyboard yang telah dibuat akan dikonsultasikan kepada ahli materi dan media. Revisi dan perbaikan akan dilakukan jika desain tersebut belum sesuai. Jika desain telah dinilai baik, proses pengembangan media tersebut meningkat ke tahap selanjutnya, yaitu tahap development (pembuatan produk). Pembuatan produk tersebut berpedoman pada desain dan storyboard yang telah dibuat. Struktur dalam media pembelajaran kearsipan digital disajikan pada Gambar 2.

\section{Fase Pengembangan dan Implementasi}

Pada fase ini dilakukan kegiatan produksi dalam membuat media pembelajaran kearsipan digital Media pembelajaran tersebut dibuat dengan dibantu software Microsoft Office 2010. Microsoft Office Access adalah salah satu program pengolahan berbasis data relasional (sekumpulan informasi yang saling berhubungan dan memiliki tujuan tertentu), yang canggih dengan kemudahan penggunaan yang ada seperti pengaturan data, pembuatan form, pembuatan laporan, serta dukungan penuh untuk mengolah berbagai jenis basis data dengan pengoperasian dalam Open

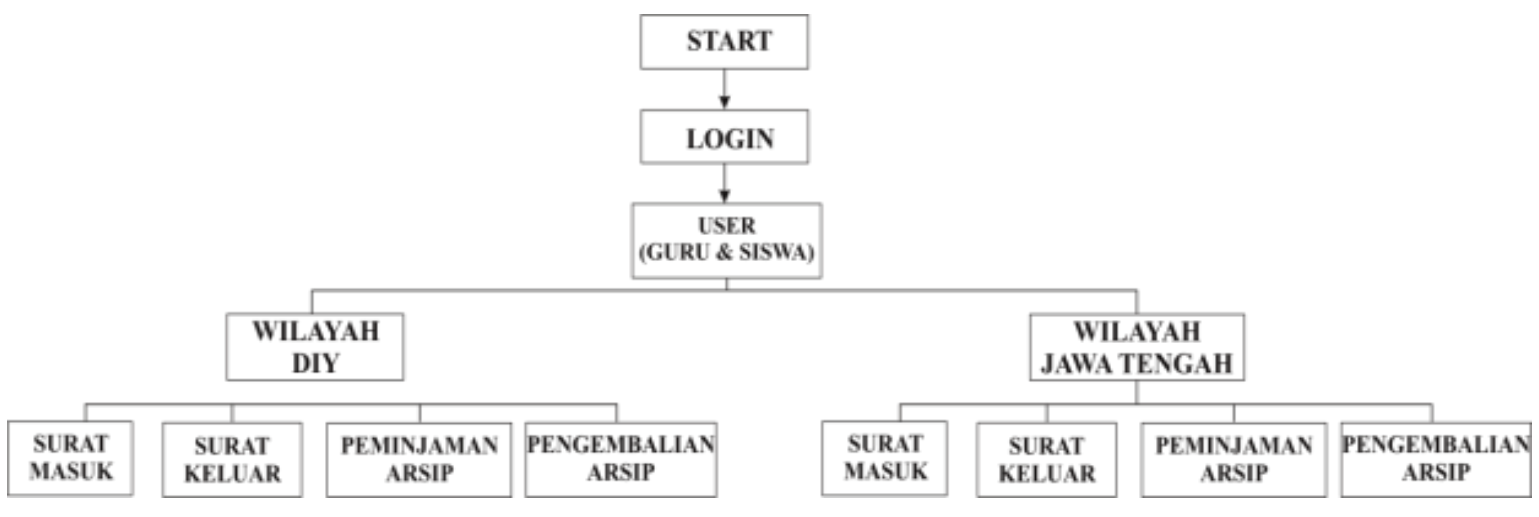

Gambar 2. Struktur Media Pembelajaran Kearsipan digital 
Database Connectivity (ODBC) dan teknologi Active $X$ Data Objects (ADO) yang membuat Microsoft Office Access sebagai database "default" dalam sistem operasi Windows.

Pembuatan arsip elektronik menggunakan Microsoft Access dengan membuat pangkalan data atau database, dengan adanya database pembuatan arsip elektronik dapat disimpan dengan baik dan terjaga. Database merupakan tempat mengelola data, baik dalam pembuatannya, mengolah, hingga temu kembali arsip yang dibutuhkan.

Dalam mengembangkan media pembelajaran kearsipan digital ini memproduksi media yang berarti mengubah naskah menjadi sistem kearsipan dalam bentuk media pembelajaran digital.

\section{Produksi Media Pembelajaran Digital}

Pada tahap produksi media pembelajaran digital ini yaitu mengubah storyboard menjadi sebuah media yang berisi teks dan beberapa menu yang dibutuhkan pada sistem kearsipan yang terdiri dari surat masuk, surat keluar, peminjaman arsip dan pengembalian arsip. Langkah-langkah dalam menjalankan media pembelajaran kearsipan digital, user yaitu siswa harus login terlebih dahulu dengan cara mengisi username dan password. Berikut merupakan beberapa tampilan yang ada di media pembelajaran kearsipan digital.

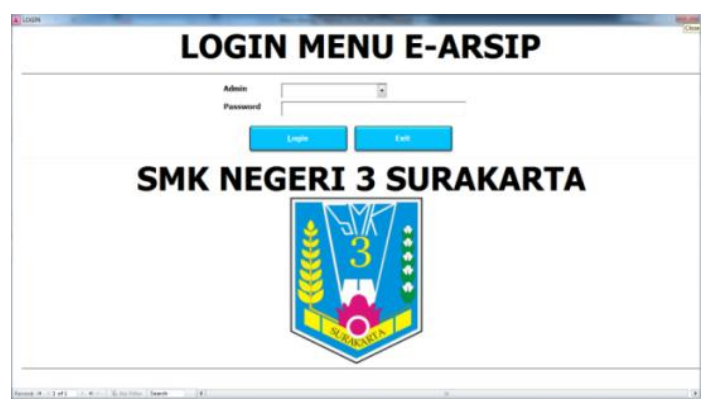

Gambar 3. Tampilan Menu Login

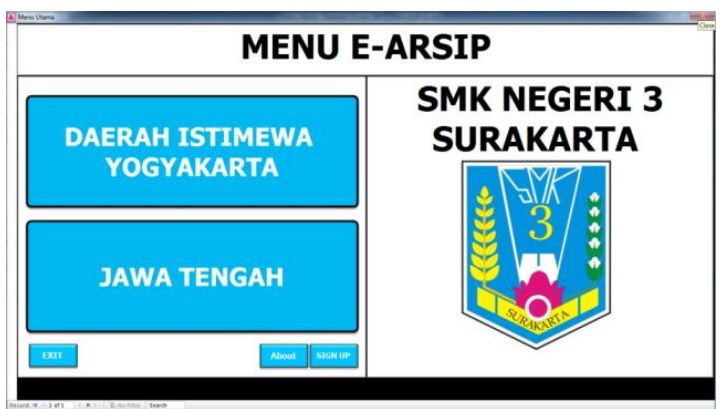

Gambar 4. Tampilan Menu E-Arsip

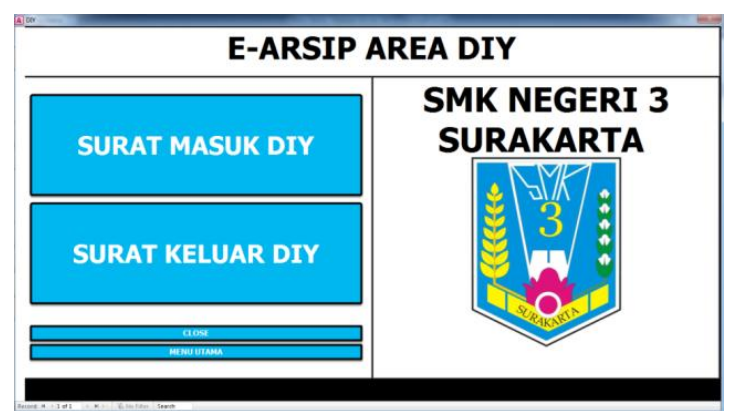

Gambar 5. Tampilan Menu Wilayah Arsip

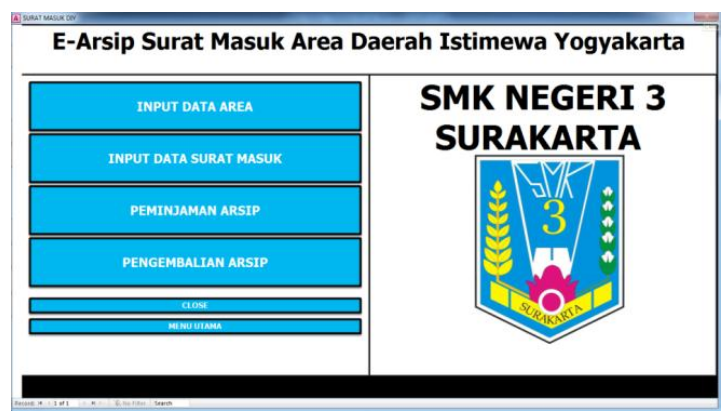

Gambar 6. Tampilan Menu Surat Masuk

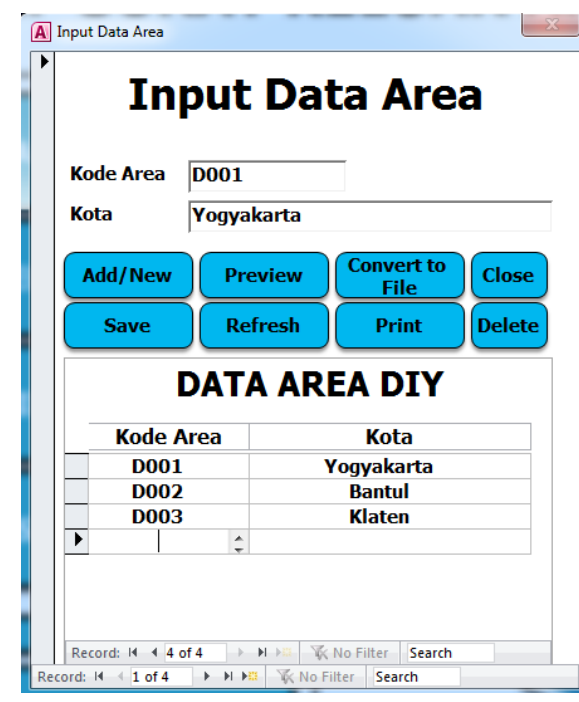

Gambar 7. Tampilan Menu Input Data Area

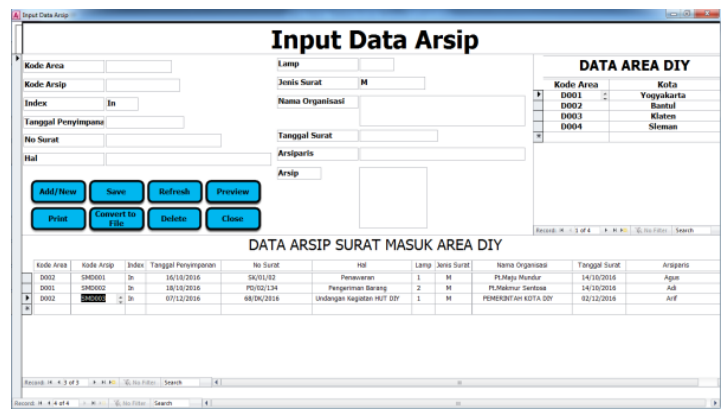

Gambar 8. Tampilan Menu Input Data Arsip 


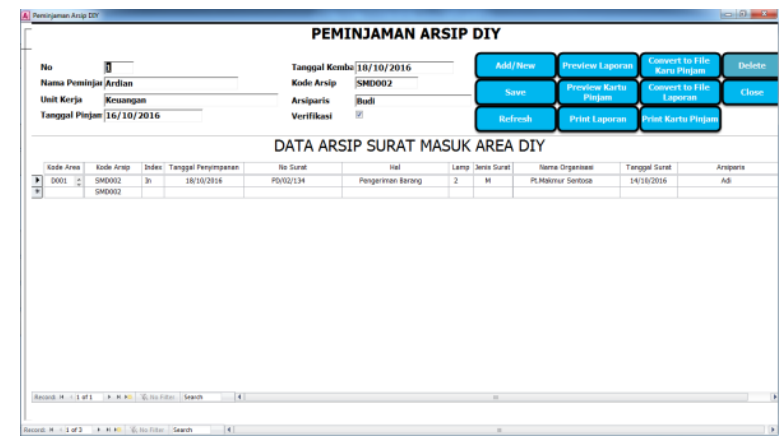

Gambar 9. Tampilan Menu Peminjaman Arsip

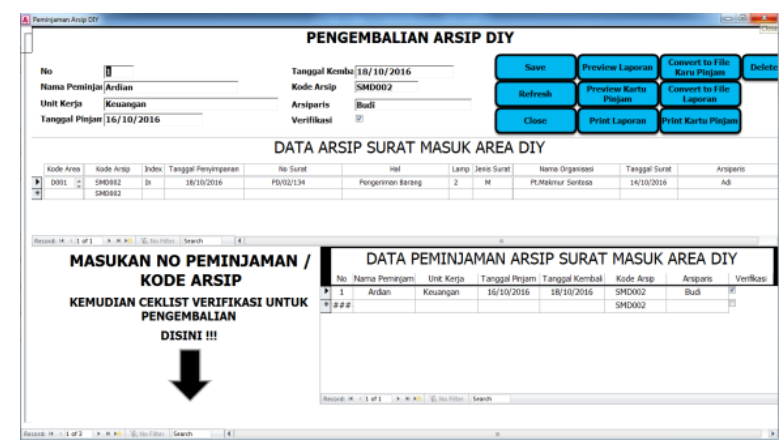

Gambar 10. Tampilan Menu

Pengembalian Arsip

Media pembelajaran kearsipan digital merupakan salah satu perangkat pembelajaran praktik yang menekankan pada pemahaman siswa pada proses penanganan arsip sebagai upaya menciptakan media pembelajaran yang menyenangkan. Media pembelajaran ini diciptakan atau dibuat dengan program Microsoft Office Acces 2013. Microsoft Office Access (Ms. Access) adalah sistem pengolahan database yang bersifat RDBMS (Relational Database Management System). Database pada Microsoft Acces adalah sekumpulan objek yang terdiri dari table, query, form, report.

\section{Pascaproduksi Media Pembelajaran Ke- arsipan Digital}

Tahap ini merupakan tahap yang menyatakan bahwa media pembelajaran kearsipan digital telah selesai, selanjutnya untuk dikonsultasikan dengan ahli materi dan ahli media beserta dengan penilaian dan masukanmasukan yang diberikan. Hal ini dilakukan untuk mengetahui kelebihan dan kekurang dari konsep dasar yang sudah dibuat tersebut. Konsultasi kepada ahli media dan ahli materi dilakukan sesuai dengan revisi atau masukan.
Setelah revisi dilakukan maka dilanjutkan dengan uji coba kepada siswa.

Pengolahan data berikutnya yaitu melakukan uji normalitas dan uji homogenitas. Uji normalitas bertujuan untuk melihat apakah variansi kelas eksperimen dan kelas kontrol berdistribusi normal atau tidak. Uji normalitas dilakukan dengan menggunakan uji lilifors. Sedangkan uji homogenitas dilakukan untuk mengetahui apakah variansi kedua kelas homogen (sama) atau tidak) dengan menggunakan uji bartlet. Setelah itu, dilakukan perhitungan uji-t, hal ini dilakukan untuk melihat apakah terdapat perbedaan hasil belajar dan prestasi belajar yang dicapai antara kelas kontrol dan kelas eksperimen setelah menggunakan media pembelajaran digital berbasis Microsoft Access.

\section{Pembahasan}

Media pembelajaran kearsipan digital dimulai dengan tahap analisis kebutuhan. Model pengembangan yang digunakan adalah model pengembangan produk pembelajaran Hannafin and Peck dalam Tegeh, Jampel dan Pudjawan (2014, p. 1) yang terdiri dari Fase Analisis Kebutuhan, Fase Desain, Fase Pengembangan dan Implementasi. Pada tahap pertama adalah analisis yang terdiri dari dua tahap yaitu studi pustaka dan analisis kebutuhan.

Pada tahap pertama peneliti melakukan analisis mengenai permasalahan untuk mengembangkan media pembelajaran kearsipan digital, yaitu dengan melakukan observasi dan wawancara dengan guru mata pelajaran kearsipan. Setelah menemukan permasalahanpermasalahan yang ditemukan di lapangan maka selanjutnya adalah merumuskan tujuan dari pengembangan media pembelajaran kearsipan digital. Berdasarkan hasil hasil dari studi lapangan dan tahap analisis di ketahui permasalahan bahwa guru mengalami kesulitan ketika menyampaikan materi pada mata pelajaran kearsipan. Guru juga kesulitan membuat media pembelajaran sehingga kesulitan dalam memberikan contoh visual kepada siswa. Selain itu guru di dalam kelas menerangkan materi, sehingga pelajaran tidak dapat diterima dengan baik.

Pada tahap kedua dalah menentukan cakupan isi basis data, yaitu pengembangan materi dalam media pembelajaran kearsipan 
digital berdasarkan analisis kebutuhan materi. Setelah tahap penentuan cakupan isi basis data maka selanjutnya adalah tahap desain. Pada tahap ini dibuat kerangka struktur program dan storyboard. Pembuatan struktur program dan storyboard bertujuan agar produk yang akan dibuat dapat terdesain, baik itu untuk tampilan produk serta isi dari media pembelajaran kearsipan digital. Tahap selanjutnya adalah prototyping, yaitu pembuatan produk dalam skala kecil sebagai produk awal.

Selama uji coba dikumpulkan kekurangan-kekurangan yang masih perlu diperbaiki dan keinginan-keinginan pengguna yang belum terpenuhi. Setelah produk awal telah dibuat, maka tahap selanjutnya adalah pengujian atau testing produk. Penilaian produk dilakukan dengan dua tahap yaitu alpha test dan beta test. Alpha test berupa validasi yang dilakukan oleh ahli media dan ahli materi. Sedangkan beta test merupakan penilaian yang dilakukan oleh pengguna yaitu peserta didik kelas X Bidang Keahlian Administrasi Perkantoran SMK Negeri 3 Surakarta.

Tahap ketiga yaitu tahap pengembangan dan implementasi diawali dengan validasi produk oleh ahli materi dan ahli media, setelah itu dilanjutkan dengan uji small group evaluation. Menurut (Daryanto, 2010, p. 22) validasi merupakan proses untuk menguji kesesuaian mededia dengan kompetensi yang menjadi target belajar. Tahap implementasi merupakan tahap field test dimana terdapat dua kelompok kelas (eksperimen dan kontrol). Kelompok eksperimen adalah kelompok siswa yang menggunakan media pembelajaran digital, sedangkan kelompok kontrol adalah siswa yang menggunakan bahan ajar buku teks. Uji keefektifan produk dilakukan untuk mendapatkan produk yang layak dan berkualitas dari segi isi materi dan media itu sendiri. Setelah produk dinyatakan layak, maka media pembelajaran ini dapat digunakan dalam mata pelajaran kearsipan. Analisis kelayakan produk diperoleh dari data hasil pengisisan angket/lembar evaluasi dari ahli materi, ahli media, dan angket uji coba produk pada siswa, sedangkan keefektifan produk diperoleh dari hasil tes prestasi siswa.

Berdasarkan kriteria kelayakan media pembelajaran kearsipan digital hasil penilaian dari ahli media memperoleh aspek rata-rata sebesar 4,4 (sangat baik), ahli materi memperoleh aspek rata-rata sebesar 4,5 (sangat baik), dan praktisi memperoleh aspek rata-rata sebesar 4,7 (sangat baik).

Berdasarkan uji t-test (Independent Samples Test) pretest kelas eksperimen dan kelas kontrol diketahui bahwa nilai signifikansi uji-t adalah 0,296. Nilai signifikansi tersebut lebih besar dari 0,05 yang berarti bahwa $\mathrm{H}_{0}$ tidak ditolak serta nilai t-hitung adalah sebesar 1,053 < $\mathrm{t}_{\text {tabel }}$ yaitu sebesar 2,00. Hal ini menunjukkan tidak ada perbedaan yang signifikansi rata-rata hasil belajar siswa antara kelas eksperimen dan kelas kontrol pada saat pretest, selanjutnya baik kelas eksperimen dan kelas kontrol diberikan suatu perlakuan, dimana kelas eksperimen diberikan perlakuan dengan menggunakan media pembelajaran kearsipan digital dan kelas kontrol tidak diberikan media pembelajaran kearsipan digital, tetapi belajar menggunakan buku paket yang tersedia disekolah. Artinya kelas eksperimen diberikan perlakuan berupa media pembelajaran yang telah dikembangkan dan kelas kontrol tidak diberikan perlakuan dengan menggunakan media pembelajaran.

Media pembelajaran kearsipan digital diimplementasikan pada kelas yang disebut kelas eksperimen, yaitu kelas yang menggunakan media pembelajaran digital berbasis Microsoft Access dalam pembelajaran. Sedangkan sebagai pembanding atau disebut juga kelas kontrol adalah kelas yang tidak menggunakan media pembelajaran digital berbasis Microsoft Access dalam pembelajaran (hanya menggunakan buku teks). Analisis yang dilakukan pada tahap ini adalah analisis butir soal. Langkah ini dilakukan untuk mengetahui kualitas butir soal yang akan digunakan pada tes prestasi. Analisis dilakukan dengan menggunakan Ms. Excel dan IBM SPSS 20.

Hasil posttest diperoleh nilai mean atau nilai rata-rata posttest kelas eksperimen adalah 80,59 dan nilai mean atau nilai ratarata posttest kelas kontrol adalah 77,97. Berdasarkan hasil penilaian tersebut diketahui bahwa nilai yang diperoleh kelas eksperimen lebih tinggi dari kelas kontrol. Hasil nilai kelas eksperimen sebelum menggunakan media pembelajaran kearsipan digital diperoleh ratarata 69,26 dan setelah dilakukan perlakuan menggunakan media pembelajaran kearsipan digital nilai rata-rata posttest meningkat menjadi 80,59. Hasil kenaikan rata-rata nilai hasil belajar mata pelajaran kearsipan sebelum 
(pretest) dan sesudah (posttest) menggunakan media pembelajaran kearsipan digital menunjukkan bahwa media pembelajaran kearsipan digital efektif meningkatkan hasil belajar siswa. Hal ini didukung oleh penelitian yang dilakukan oleh (Hariyati, 2014, p. 14) menyatakan bahwa berdasarkan uji-t dihasilkan Jadi, $\mathrm{H}_{0}$ ditolak dan $\mathrm{H}_{1}$ diterima, artinya ada pengaruh yang signifikan antara penggunaan media pembelajaran terhadap hasil belajar siswa dalam pembelajaran IPS Terpadu di SMP 12 Palu, dapat dilihat dengan koefisien korelasi sebesar 0,797 sehingga dikategorikan kuat. Selanjutnya hasil penelitian yang dilakukan oleh Chou, Chang, \& Lu (2015, p. 81) mengatakan bahwa "manfaat media dalam proses belajar adalah bahan pengajaran akan lebih jelas maknanya sehingga dapat lebih dipahami oleh siswa dan memungkinkan siswa untuk menguasai tujuan pembelajaran lebih baik.

Berdasarkan uraian tersebut, dapat kita ketahui bahwa penggunaan media pembelajaran merupakan faktor yang sangat penting untuk meningkatkan hasil belajar siswa dalam proses pembelajaran, karena media pembelajaran merupakan salah satu sarana yang sangat mendukung dalam pengembangan ilmu pengetahuan yang dimiliki oleh seseorang, terutama dalam proses pembelajaran di sekolah. Sehingga pihak sekolah hendaknya memperhatikan dan menyediakan media pendidikan secara lengkap agar proses pembelajaran di kelas dapat berjalan dengan efektif, karena siswa lebih termotivasi untuk belajar jika pelajaran dijelaskan dengan disertai praktek secara langsung. Selain itu, pelajaran juga lebih mudah dipahami sehingga pada saat ulangan harian dan ujian semester siswa dapat menjawab soal-soal ujian.

\section{SIMPULAN}

Media pembelajaran kearsipan digital efektif meningkatkan hasil belajar siswa. Keefektifan media pembelajaran didasarkan pada hasil pretest (sebelum menggunakan media pembelajaran kearsipan digital) diperoleh rata-rata nilai 69,26 dan posttest (sesudah menggunakan media pembelajaran kearsipan digital) diperoleh rata-rata 80,59 pada saat uji coba lapangan. Kenaikan rata-rata nilai hasil belajar pretest (sebelum) dan posttest (sesudah) menggunakan media pembelajaran kearsipan digital menunjukkan bahwa media pembelajaran kearsipan digital efektif dalam meningkatkan hasil belajar siswa.

Penggunaan media pembelajaran kearsipan digital efektif meningkatkan hasil belajar siswa didukung oleh perhitungan statistik dan di dapat nilai signifikansi $=0,002$ $<0,005$ pada saat uji efektifitas antara kelas eksperimen dan kelas kontrol menunjukkan perbedaan yang signifikansi, bahwa nilai ratarata kelas eksperimen adalah 80,59 dan kelas kontrol 77,97. Berdasarkan nilai rata-rata hasil belajar posttest (setelah diberi perlakuan) maka dapat disimpulkan bahwa nilai kelas eksperimen lebih baik dibandingkan dengan nilai kelas kontrol.

\section{DAFTAR PUSTAKA}

Afandi, M., \& Badarudin. (2011). Perencanaan pembelajaran. Bandung: Alfabeta.

Akyuz, S., \& Yavuz, F. (2015). Digital learning in EFL classrooms. Procedia Social and Behavioral Sciences, 197, 766-769.

https://doi.org/http://dx.doi.org/10.1016/ j.sbspro.2015.07.176

All, A., Nuñez Castellar, E. P., \& Van Looy, J. (2016). Assessing the effectiveness of digital game-based learning: Best practices. Computers \& Education, 9293, 90-103. https://doi.org/http://dx.doi.org/10.1016/ j.compedu.2015.10.007

Borg, W. R., \& Gall, M. D. (2007). Education research: an introduction. New York: Longman.

Chou, P.-N., Chang, C.-C., \& Lu, P.-F. (2015). Prezi versus PowerPoint: The effects of varied digital presentation tools on students' learning performance. Computers \& Education, 91, 73-82. https://doi.org/http://dx.doi.org/10.1016/ j.compedu.2015.10.020

Cincinelli, A., Martellini, T., Amore, A., Dei, L., Marrazza, G., Carretti, E., ... Leva, P. (2016). Measurement of volatile organic compounds (VOCs) in libraries and archives in Florence (Italy). Science of The Total Environment, 572, 333339. 
https://doi.org/http://dx.doi.org/10.1016/ j.scitotenv.2016.07.201

Daryanto. (2010). Media pembelajaran. Yogyakarta: Gava Media.

Ferro, N., \& Silvello, G. (2013). NESTOR: A formal model for digital archives. Information Processing \& Management, 49(6), $1206-1240$ https://doi.org/http://dx.doi.org/10.1016/ j.ipm.2013.05.001

Gan, B., Menkhoff, T., \& Smith, R. (2015). Enhancing students' learning process through interactive digital media: New opportunities for collaborative learning. Computers in Human Behavior, 51, Part $B$, 652-663. https://doi.org/http://dx.doi.org/10.1016/ j.chb.2014.12.048

Hamalik, O. (2011). Proses belajar mengajar. Jakarta: Bumi Aksara.

Hannafin, M., \& Peck, K. (1988). The design development and evaluation of instructional software. New York: MacMillian Publishing.

Hariyati. (2014). Pengaruh penggunaan media pembelajaran terhadap hasil belajar siswa pada mata pelajaran IPS Terpadu di SMP Negeri 12 Palu. E- Journal GeoTadulako UNTAD.

Lock, R. H., \& Kingsley, K. V. (2007). Empower diverse learners with educational technology and digital media. Intervention in School and Clinic, 43(1), 52-56. https://doi.org/10.1177/10534512070430 010701

Norman, E., \& Furnes, B. (2016). The relationship between metacognitive experiences and learning: Is there a difference between digital and nondigital study media? Computers in Human Behavior, 54, 301-309. https://doi.org/http://dx.doi.org/10.1016/ j.chb.2015.07.043

Rosalin, E. (2008). Guru dalam meningkatkan daya pikir siswa. Jurnal Manajemen Pendidikan UPI, Tahun IV.(No.01).

Smith, K. G. (2016). Negotiating community literacy practice: public memory work and the Boston marathon bombing digital archive. Computers and Composition, 40, 115-130. https://doi.org/http://dx.doi.org/10.1016/ j.compcom.2016.03.003

Tang, X., Misztal, P. K., Nazaroff, W. W., \& Goldstein, A. H. (2015). Siloxanes are the most abundant volatile organic compound emitted from engineering students in a classroom. Environmental Science \& Technology Letters, 2(11), 303-307.

https://doi.org/10.1021/acs.estlett.5b002 56

Tegeh, I. M., Jampel, I. N., \& Pudjawan, K. (2014). Model penelitian pengembangan. Yogyakarta: Graha Ilmu.

UNCTAD. (2005). Globalization of R \& D and developing countries. In Proceding of the Expert Meeting Geneva 24-25 January 2005. New York \& Geneva United Nation Publication.

Westriningsih. (2010). Panduan praktis Microsoft Office 2010. Yogyakarta: Andi.

Yuliana, O. Y. (2007). Langkah jitu pembuatan aplikasi database Microsoft Access. Yogyakarta: Graha Ilmu. 